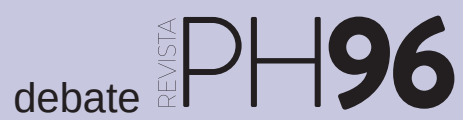

a debate Memoria democrática en la construcción de la historia y el patrimonio

| coordina Josefina Cuesta Bustillo

\title{
Debates sobre la memoria como patrimonio colectivo
}

Jordi Guixé Coromines | director del European Observatory on Memories

URL de la contribución <www.iaph.es/revistaph/index.php/revistaph/article/view/4277>

La amiga y maestra Josefina Cuesta, coordinadora de este debate, lleva toda la razón al referirse al mito de Antígona para tratar el tema de la memoria irresoluta en España. La necesidad de impulsar políticas de memoria democrática en España es una responsabilidad colectiva que solamente la soberbia de algunos gobiernos ha pretendido eludir. El trabajo de memoria en el siglo XXI es imperativamente transnacional, interdisciplinar, social y participativo, institucional, universitario y debería ser profesional.

Hablar de consenso o reconciliación en la España del 2018 es complejo, pues todavía se impone un relato entre vencedores y vencidos que impide avanzar en el trabajo de memorias -en plural-. No es lo mismo reconocer errores que reconocer culpabilidades. Es ahí donde no podemos entrar en lo políticamente incorrecto, pero hay una parte de bloqueo memorial que pasa imperativamente por reconocer culpabilidades de Estado. Errores, el pasado es muchas veces un gran Error, pero culpabilidades y responsabilidades de crímenes de Estado durante periodos de no guerra en este país no se han reconocido. La culpa en Alemania fue en parte impuesta por la derrota, por la judicialización, pero también por la nueva democracia que proclamó la memoria como herramienta reparativa. Algunos hablan ya de hipertrofia para el caso alemán, pero cuando entramos en detalles e investigaciones, vemos que el daño realizado nunca podrá ser suficientemente reparado. ¿Por qué en España no se puede realizar un proceso -no igual- pero parecido? Porque todavía hay orgullo de victoria y cierta impunidad chulesca.

Ante estas posturas, configuradas por muchos mitos, intereses de casta y por la timidez de políticas públicas de memoria, la Administración ha necesitado, delante y detrás, el empujón de asociaciones -sobre todo de vícti- mas-, de expertos y de proyectos profesionales o patrimoniales para impulsar una política de memoria irregular, mal estructurada y, sobre todo, low-cost. No es un caso único, pues en la mayoría de países la ciudadanía "ha tirado del carro", pero también el Estado lo ha seguido.

Una de las vías de implementación que más cuesta es la recuperación y creación de espacios patrimoniales memoriales. De recuperación de lugares de memoria. Pienso que responde al mismo miedo o timidez. Las excusas son presupuestarias, pero en definitiva los actores públicos no entienden que, precisamente, una manera de superar el bloqueo memorial en nuestro país es crear estos lugares. Lugares pedagógicos, de aprendizaje, de reparación de dignificación de un pasado traumático y/o violento, pero también de conservación e interpretación histórica y memorial. Llanamente podría afirmar que la memoria como proceso es más conflictiva durante las discusiones políticas que durante la práctica ejecución memorial.

La memoria democrática es patrimonio tangible e intangible, pero es patrimonio. La inmaterialidad del testimonio puede resignificar la memoria junto a la materialidad de un espacio, una fosa, una cárcel, una trinchera. Para que la discusión, los valores y el conocimiento emerjan en estos espacios patrimoniales, hace falta de intervenciones valientes y, muchas veces, esfuerzos presupuestarios. Una vez que se musealiza, se interviene, se grava un testimonio, el efecto reparador y educador sobrepasa el debate político y se convierte en una herramienta de consolidación y crecimiento democrático. Miles de ejemplos bastan. Pero nos encontramos que en nuestro país tenemos miles de bonitos museos y centros de interpretación de todo tipo, en cambio, nada de memoriales, museos de memoria, lugares recuperados o centros de interpretación de nuestro pasado. Un pasado denso y 
a debate Memoria democrática en la construcción de la historia y el patrimonio

| coordina Josefina Cuesta Bustillo

conflictivo, no lo ignoramos, con un enfrentamiento muy potente provocado por la Guerra Civil, pero ensalzada a la máxima división por una dictadura demasiado longeva.

$\mathrm{Y}$ respondo a las preguntas que se plantean en este debate.

La multiplicidad memorial es la clave para entender que estamos rodeados de diversidad memorial múltiple. Una cosa es conocer la historia; la otra decidir qué conmemoramos y cómo, qué memorias deben ser rescatadas del olvido por decencia democrática y justicia social; y qué memorias son o pueden ser nostálgicas de periodos dictatoriales. Es un tema muy complejo, pero también en términos memoriales hay líneas rojas de cómo debemos mimar y ser vigilantes con nuestra democracia y libertades. Imponer mitos no significa la equiparación memorial.

¿Cómo conjugamos memoria, experiencia, sentimientos y percepciones? Yo diría que con las emociones y a través de herramientas de transmisión e interpretación. En los lugares memoriales, en los medios públicos o el espacio público. Desde la narración histórica hasta el arte contemporáneo y la performance.

Por otro lado, pienso que la memoria es conflicto, proceso y transgresión, de ahí su ADN conflictual. Y que los procesos memoriales no deberían resolver nada. El enfrentamiento político en democracia se resuelve en el Parlamento democrático, nuestra ágora política y en las elecciones, donde expresamos nuestra opinión sobre las ideas y la gestión pública. Ese es el debate. Se evita un mal uso de la memoria desde la profesionalidad, conociendo antes de actuar, con memorias comparadas transnacionales para aprender de procesos y, sobre todo, desde la gestión social y autónoma de la memoria, lo más lejos posible del poder político que dicta memorias a la carta y al uso. No conviene ejemplos como la actual Polonia o Hungría.

En relación con la retirada de nuestros espacios públicos de símbolos asociados a totalitarismos, fascismos, dictaduras o épocas históricas en las que no se han res- petado los derechos humanos o su posible conservación para uso pedagógico... Cuando dirigí el censo de simbología franquista, primero investigamos y, luego, en un informe no vinculante, decidimos "mojarnos" y no destruir ni demoler todos los símbolos. De esto resultó que la conservación, museización, reinterpretación, traslado, pedagogía, memorialización, etc. son vías de avance democrático que impiden olvidar o crear espacios asépticos con la simple retirada de símbolos. De ahí hasta la realización de dos informes sobre el Valle de los Caídos y sobre Caídos de Pamplona defienden la teoría de no destruir todo, a pesar de la ofensa que ocasiona la nula intervención.

Para responder a la pregunta sobre cómo llevar a cabo la labor de difusión e interpretación de la memoria democrática sin que suponga una banalización de la historia me remito a lo anterior: con conocimiento y formación profesional y con memoria comparada transnacional. No debemos dejarnos llevar solamente por la opinión o acción mediática-política. En este sentido estamos elaborando una especie de decálogo profesional de memoria a escala europea avalada por otras redes de memoria consolidadas y profesionales.

Por último, comparto un proyecto de puesta en valor de la memoria democrática desde una perspectiva de género. Me refiero a todo el proceso de memoria participativa sobre la desaparecida Cárcel de mujeres de les Corts de Barcelona en el que estamos muy implicados. Todo un colectivo de mujeres de la ciudad han creado una plataforma y lleva más de 10 años impulsando un proyecto sobre la invisibilidad de género y memoria: invisibilidad resistente y represiva de las presas de dicha cárcel durante el franquismo; invisibilidad de género; invisibilidad patrimonial: la cárcel se destruyó en 1956 y ahora se encuentra un Corte Inglés; invisibilidad pública porque hasta ahora ha habido una falta total de conmemoración, marcaje, explicación, etc., de esta historia y memoria en el espacio y las políticas públicas de la ciudad. Para conocer el proyecto y el el blog del proceso memorial os remitimos a los enlaces: www.presodelescorts.org y https://presodedones.wordpress.com 